\title{
Effects of dietary supplementation of selenium and iodine on growth performance, carcass characteristics and histology of thyroid gland in goats
}

\begin{abstract}
This study assessed the effects of dietary selenium (Se), iodine (I) and a combination of both on growth performance, thyroid gland activity, carcass characteristics and the concentration of iodine and selenium in Longissimus lumborum (LL) muscle in goats. Twenty-four bucks were randomly assigned to four dietary treatments: control $(\mathrm{CON})$, basal diet without supplementation, basal diet + $0.6 \mathrm{mg} \mathrm{Se} / \mathrm{kg}$ dry matter (DM) (SS), $0.6 \mathrm{mg} \mathrm{I} / \mathrm{kg} \mathrm{DM}$ (IP), or combination of $0.6 \mathrm{mg} / \mathrm{kg}$ DM Se and $0.6 \mathrm{mg} / \mathrm{kg}$ DM I (SSIP) and fed for 100 days. Animals fed diet SSIP exhibited higher $(\mathrm{P}<0.05)$ body weight and better feed conversion ratio (FCR) than those fed other diets. Dressing percentage of goats fed the supplemented diets was higher $(\mathrm{P}<0.05)$ than that of the control. Carcasses from the IP group had higher $(\mathrm{P}<0.05)$ total fat proportion than the SSIP group. The levels of both elements were significantly elevated $(\mathrm{P}<0.05)$ in LL muscle in supplemented goats. Thyroid follicular epithelial cells of IP and SSIP animals were significantly higher than those of CON and SS groups. The study demonstrated that the combined Se and I dietary supplementation improves growth performance, carcass dressing percentage and increases the retention of Se and I in goat meat.
\end{abstract}

Keyword: Goat meat; Growth; Iodine; Selenium; Thyroid gland 